\title{
Edukacja osób z niepełnosprawnością w systemie niesegregacyjnym - wykluczające czy dopełniające się formy kształcenia
}

\begin{abstract}
Jarosław Bąbka, Edukacja osób z niepetnosprawnością w systemie niesegregacyjnym - wykluczajace czy dopetniajace sie formy ksztatcenia [Education of the Disabled in the Non-segregation system - Exclusive or Complementary Forms of education]. Interdyscyplinarne Konteksty Pedagogiki Specjalnej, nr 11, Poznań 2015. Pp. 9-33. Adam Mickiewicz University Press. ISSN 2300-391X
\end{abstract}

The paper analyses changes in the educational approach towards the disabled illustrated with an example of integrative and inclusive education as well as shows differences and similarities between them. The analysis is completed with a picture of versions of non-segregation education resulting from various educational discourses. Due to a social aspect of the activities comprised by integrative and exclusive teaching the analysed forms of education were treated as a kind of intervention into the process of socialization. The aim of such an intervention is to develop activity competence with pupils and to prepare young generation for accepting people's differences, mutual coexistence, dialogue and cooperation. The author tries to stress, that the analysed forms of the non-segregation education should in practice be treated as complementary and not as exclusive. Implementation of the concepts of inclusive education, as a direction of the postulated changes in education, which is a result of the Convention on the Rights of People with Disabilities, requires changes in all directions. They refer to, among other things: legal regulations ensuring implementation of standards related to organization and offering classes promoting development of pupils with disabilities, changes in the training system of teachers 
and preparing them for work with pupils with individual educational and developmental needs.

KEY WORDS: educational discourses, integrative education, inclusive education, disability

\section{Wprowadzenie}

Pojęcie edukacji niesegregacyjnej odnosi się do dwóch form kształcenia uczniów z niepełnosprawnością, tj. w oddziałach integracyjnych oraz klasach powszechnych zgodnie z rejonem zamieszkania. Te dwie formy kształcenia $\mathrm{w}$ niniejszej pracy traktowane są jako dopełniające się, a nie wykluczające. Wraz z upowszechnianiem się idei normalizacji, nowych szans na zmianę sytuacji osób $\mathrm{z}$ niepełnosprawnością upatruje się $\mathrm{w}$ edukacji włączającej (ang. inclusive education). W ratyfikowanej przez Polskę w 2012 r. Konwencji o Prawach Osób Niepełnosprawnych eksponuje się system edukacji włączającej ${ }^{1}$. Kształcenie włączające jako idea szkoły dla różnorodności uczniów to ciekawa koncepcja, która jednocześnie budzi wiele wątpliwości: co ze szkołami specjalnymi i klasami integracyjnymi? Czy każda szkoła powszechna jest gotowa uwzględnić różnorodność swoich wychowanków? W Niemczech, jak podaje Otto Speck², wraz z przyjęciem Konwencji o Prawach Osób Niepełnosprawnych postulowano likwidację szkół specjalnych. Zakładano

${ }^{1}$ Edukacja włączająca została w sposób szczególny uprawomocniona w Konwencji o Prawach Osób Niepełnosprawnych, ratyfikowanej przez Polskę w 2012. W artykule 24 - Edukacja - podkreśla się prawo osób niepełnosprawnych do kształcenia. Państwa powinny zapewnić osobom z niepełnosprawnością system edukacji włączającej (obejmującej wszystkie poziomy edukacji, łącznie $\mathrm{z}$ edukacją ustawiczną). Zmiany $\mathrm{w}$ polityce oświatowej na rzecz edukacji włączającej znajdują wyraz w Rozporządzeniu MEN z dnia 24 lipca 2015 r. w sprawie warunków organizowania kształcenia, wychowania i opieki dla dzieci i młodzieży niepełnosprawnych, niedostosowanych społecznie i zagrożonych niedostosowaniem społecznym (Dz.U. z 2015 r., poz. 1113).

2 O. Speck, Inkluzja edukacyjna a pedagogika lecznicza, Harmonia, Gdańsk 2013, s. 49. 
także likwidację klas integracyjnych, nie dlatego, że nie spełniają oczekiwań, ale dlatego, że są zbyt kosztowne ${ }^{3}$. W tym kontekście warto się zastanowić, czy wypieranie pojęcia "społeczna integracja” bez zmian w filozofii edukacji oraz zastępowanie jej pojęciem społecznej inkluzji, a także nacisk na kształcenie włączające jako postulowany kierunek zmian oświatowych zgodny z tendencjami europejskimi doprowadzi do uzyskania w szkole lepszych rezultatów dydaktycznych i społecznych?

Niniejsze opracowanie ma na celu: (1) ukazanie przemian w edukacji niesegregacyjnej osób z niepełnosprawnością na przykładzie kształcenia integracyjnego oraz włączającego, (2) omówienie różnic i podobieństw pomiędzy analizowanymi formami edukacji niesegregacyjnej, (3) podkreślenie, że skuteczność form edukacji niesegregacyjnej nie tkwi w nomenklaturze i zastępowaniu, zgodnie $\mathrm{z}$ obowiązującymi trendami, jednych pojęć drugimi, ale w przemianach w myśleniu o edukacji oraz działaniu pedagogicznym, którego źródła tkwią w różnych paradygmatach i dyskursach edukacyjnych.

\section{Koncepcje wyjaśniające edukację osób z niepełnosprawnością w systemie niesegregacyjnym}

Problem edukacji osób z niepełnosprawnością w systemie niesegregacyjnym należy ujmować w jak najszerszej perspektywie. Takiemu podejściu sprzyja koncepcja struktury społecznej i rozwoju osobowości wg Klausa Hurrelmanna4. Autor podejmował w niej

3 Takie obawy mają miejsce w polskich szkołach. Na konsultacjach społecznych dotyczących organizacji edukacji uczniów z niepełnosprawnością, które odbyły się w Poznaniu 9 marca 2015 r., przedstawiciele MEN zapewnili, że w Polsce przewiduje się możliwość realizacji trzech ścieżek edukacyjnych: (1) w przedszkolach, szkołach i ośrodkach specjalnych, (2) w przedszkolach i szkołach z oddziałami integracyjnymi oraz (3) w przedszkolach i szkołach powszechnych.

${ }^{4} \mathrm{~K}$. Hurrelmann, Struktura społeczna a rozwój osobowości. Wprowadzenie do teorii socjalizacji, Wydawnictwo Naukowe UAM, Poznań 1994. 
kwestie osobowości, wychowania i socjalizacji, a także próbował pogodzić stanowiska socjologiczne oraz psychologiczne. Szeroka perspektywa koncepcji socjalizacji umożliwia odwołanie się do innych teoretycznych ujęć: ekologicznej koncepcji rozwoju według Uriego Bronfenbrennera5, psychologicznych koncepcji człowieka6, założeń ideologii romantycznej, transmisji kulturowej, progresywizmu wg Lawrence'a Kohlberga i Rochelle Mayer7, założeń pedagogiki krytycznej reprezentowanej przez Michela Foucaulta8, Henry'ego Girouxa9 ${ }^{\prime}$, poglądów neopragmatysty Richarda Rorty'ego ${ }^{10}$.

Funkcjonowanie ucznia $\mathrm{z}$ niepełnosprawnością $\mathrm{w}$ szkole jako mikrosystemie, zgodnie z koncepcją Uriego Bronfernbernnera, należy ujmować w kontekście przeobrażeń makrosystemowych na przestrzeni ostatnich 20 lat. Dotyczą one przemian w paradygmatach nauk społecznych, wartościach, postawach wobec jednostek w jakiś sposób innych oraz zmian w polityce państwa na rzecz osób z ograniczeniami sprawności, poprzez realizację międzynarodowych deklaracji i konwencji11.

5 U. Bronfenbrenner, The Ecology of Human Development, Harvard University Press, Cambridge 1979.

${ }^{6}$ J. Kozielecki, Koncepcje psychologiczne człowieka, Wydawnictwo Akademickie „Żak”, Warszawa 1995.

${ }^{7}$ L. Kohlberg, R. Mayer, Rozwój jako cel wychowania, [w:] Spory o edukację. Dylematy i kontrowersje we wspótczesnych pedagogiach, red. Z. Kwieciński, L. Witkowski, Instytut Badań Edukacyjnych, Warszawa 1993, s. 51-94.

8 S.J. Ball, Foucault i edukacja. Dyscypliny i wiedza, Oficyna Wydawnicza „Impuls", Kraków 1992.

${ }^{9}$ H.A. Giroux, Wobec wyzwań tożsamości i różnicy (Poza dyskurs edukacji wielokulturowej), [w:] Edukacja wobec zmiany społecznej, red. J. Brzeziński, L. Witkowski, Edytor, Torun 1994, s. 413-434.

${ }^{10}$ R. Rorty, Filozofia a nadzieja na lepsze społeczeństwo, Wydawnictwo Naukowe Uniwersytetu Mikołaja Kopernika, Toruń 2013.

11 Wśród wielu międzynarodowych dokumentów warunkujących kreowanie polityki oświatowej na rzecz osób z niepełnosprawnością wymienię kilka: (1) Deklarację z Salamanki (1994) oraz Wytyczne dla działania w zakresie specjalnych potrzeb edukacyjnych przyjęte przez Światową Konferencję dotyczącą Specjalnych Potrzeb Edukacyjnych: Dostęp i Jakość, UNESCO, Salamanka, Hiszpania, 7-10 czerwca 1994, które uzasadniają konieczność zmian w edukacji dzieci z niepełnosprawno- 
Za Stanisławem Kowalikiem ${ }^{12}$ można wyróżnić kilka etapów przemian sytuacji osób z niepełnosprawnością oraz idei społecznej integracji:

(1) dostrzegania szkodliwego wpływu praktyk segregacyjnych oraz realizacji idei normalizacji,

(2) rozwoju idei głównego nurtu poprzez włączeniu do niego osób z niepełnosprawnością,

(3) oddziaływania na ludzi pełnosprawnych, aby przygotować ich $\mathrm{w}$ toku edukacji do akceptacji niepełnosprawnych $\mathrm{w}$ dorosłym życiu,

(4) tworzenia warunków normalizacyjnych zgodnie z ideą: „,̇̇yjesz normalnie - jesteś normalny"13 oraz upowszechniania edukacji włączającej.

Te przemiany za Władysławem Dykcikiem ${ }^{14}$ można ująć od segregacji przez integracje aż po normalizację. Amadeusz Krause ${ }^{15}$ słusznie zauważył, że idea społecznej integracji będzie dalej postępowała zgodnie ze światowymi tendencjami w kierunku normalizacji. Ta tendencja znajduje wyraz $\mathrm{w}$ upowszechnianiu kształcenia włączającego jako postulowanej formy edukacji.

Problem edukacji osób z niepełnosprawnością należy widzieć w kontekście socjalizacji jako procesu wyłaniania się jednostki twórczo przekształcającej zewnętrzną i wewnętrzną rzeczywistość $\mathrm{w}$ społecznych interakcjach ze środowiskiem społecznym, ale

ścią; (2) Deklarację Madrycką (2002), w której jeden z postulatów zakłada zmiany: Od segregacji w edukacji, zatrudnieniu i innych sferach życia do integrowania osób niepełnosprawnych w normalnym nurcie życia; (3) Konwencję o Prawach Osób Niepełnosprawnych (2006) (2012).

12 S. Kowalik, Pomiędzy dyskryminacją a integracją osób niepetnosprawnych, [w:] Wspomaganie rozwoju. Psychostymulacja i psychokorekcja, t. 3, red. B. Kaja, Wydawnictwo Uczelniane Akademii Bydgoskiej, Bydgoszcz 2001, s. 41-46.

${ }^{13}$ A. Krause, Wspótczesne paradygmaty pedagogiki specjalnej, Oficyna Wydawnicza „Impuls", Kraków 1992, s. 196.

${ }_{14}$ W. Dykcik, Wprowadzenie w przedmiot pedagogiki specjalnej jako nauki, [w:] Pedagogika specjalna, red. W. Dykcik, Wydawnictwo Naukowe UAM, Poznań 2001, s. 460.

${ }^{15} \mathrm{~A}$. Krause, Człowiek niepetnosprawny wobec przeobrażeń społecznych, Oficyna Wydawnicza „Impuls”, Kraków 1992, s. 241. 
w konkretnym historycznie określonym społeczeństwie ${ }^{16}$. K. Hurelmann ${ }^{17}$ zakładał możliwość niepomyślnej socjalizacji jednostki bez względu na jej stopień sprawności, ale też podkreślał znaczenie podejmowania różnych interwencji edukacyjnych przeciwdziałających nieprawidłowościom. $Z$ jednej strony mają one na celu doskonalenie szeroko rozumianych kompetencji jednostki, $\mathrm{z}$ drugiej zmiany w środowisku jej życia. Edukację osób z niepełnosprawnością oraz pełnosprawnych $\mathrm{w}$ systemie niesegregacyjnym należy traktować jako swoistą interwencję w proces socjalizacji. Interwencja ma na celu kształtowanie kompetencji umożliwiających wychowankom osiąganie zadań rozwojowych, a także przygotowanie młodego pokolenia do wzajemnej koegzystencji poprzez afirmację inności, jako czegoś naturalnego wśród ludzi. Takie podejście prezentuje również Otto Speck, który uważa, że „Realizacja społecznej integracji nie może całkowicie się dokonać jednie na drodze prawnej (...). Pedagogika musi tutaj wnieść swój wkład"18.

\section{Dyskursy edukacji niesegregacyjnej}

W myśleniu o edukacji niesegregacyjnej zaznacza się podejście prakseologiczne, odnoszące się głównie do sfery pedagogicznego odziaływania na wychowanków ${ }^{19}$. Istnieje potrzeba spojrzenia na problem edukacji niesegregacyjnej z metapoziomu, dzięki czemu ukazano by, że działania pedagogiczne są konsekwencją przyjmowanych przez realizatorów idei, świadomie lub nie, założeń natury ogólniejszej, np. paradygmatów, dyskursów. Każdy pedagog ma jakąś prywatną teorię edukacji czy wspomagania rozwoju ucznia. Prywatna teoria edukacji wyraża się m.in. w sposobie myślenia o pomaganiu dziecku w rozwoju, stawianych celach edukacyjnych,

${ }^{16}$ K. Hurrelmann, op. cit., s. 59.

17 Ibidem, s. 140-167.

${ }_{18}$ O. Speck, op. cit., s. 26.

${ }^{19}$ J. Gnitecki, Zarys pedagogiki ogólnej, Wojewódzki Ośrodek Metodyczny, Gorzów Wielkopolski 1999, s. 55. 
a także środkach ich uzyskiwania. Anna I. Brzezińska wyjaśnia to zjawisko następująco: „"»jak myślisz, tak działasz«, zatem "pomyśl o tym jak myślisz«, a lepiej »zrozumiesz dlaczego działasz tak, a nie inaczej «"20. Za Bogusławem Śliwerskim ${ }^{21}$ przyjęto, że rozważania pedagogiczne wymagają zastosowania pewnego porządku pojęciowego. Dlatego nadrzędną kategorią uczyniono paradygmat, a następnie dyskurs. Kierunek przemian paradygmatycznych w naukach społecznych za Teresą Hejnicką-Bezwińską22 można ująć od paradygmatu pozytywistycznego do humanistycznego. Z tak postrzeganym humanizmem wiąże się zgoda na wielość słusznych stanowisk oraz różne drogi poznania. Przyjmuje się, że pedagogika jest nauką wieloparadygmatyczną ${ }^{23}$. Joanna Rutkowiak proponuje przezwyciężenie opozycyjności paradygmatów poprzez przekład międzyparadygmatyczny, tj. poruszanie się pomiędzy paradygmatami, szukanie nowych znaczeń24. Według Amadeusza Krausego przesunięcie akcentu z naturalizmu na kulturalizm znajduje wyraz w koncepcji szczegółowych paradygmatów niepełnosprawności ${ }^{25}$, tj.: integracyjnego, normalizacyjnego, społecznego i emancypacyjnego. Iwona Chrzanowska wyróżnia dwa paradygmaty, tj. biologiczny i humanistyczny oraz przyporządkowuje im odpowiednio subparadygmat pozytywistyczny, społeczny, emancypacyjny oraz

20 A.I. Brzezińska, Pomoc dzieciom z grup ryzyka, "Remedium” 2002, 12, s. 42.

${ }^{21}$ B. Śliwerski, Wspótczesna myśl pedagogiczna. Znaczenia, klasyfikacje, badania, Oficyna Wydawnicza „Impuls”, Kraków 2011, s. 25-44.

${ }^{22}$ T. Hejnicka-Bezwińska, Paradygmat humanistyczny w pedagogice a pedagogika humanistyczna, [w:] Edukacja, moralność, sfera publiczna. Materiały z VI Ogólnopolskiego Zjazdu Pedagogicznego PTP, red. J. Rutkowiak, D. Kubinowski, M. Nowak, Oficyna Wydawnicza „Verba”, Lublin 2007, s. 462-466.

${ }^{23}$ K. Rubacha, Budowanie teorii pedagogicznych, [w:] Pedagogika, t. 1, red. Z. Kwieciński, B. Śliwerski, PWN, Warszawa 2003, s. 59-66; B. Śliwerski, Wspótczesna myśl pedagogiczna, s. 31.

${ }^{24}$ J. Rutkowiak, Wielość paradygmatów dydaktyki a wspólny mianownik realności życia. Ku pytaniom o przekłady międzyparadygmatyczne, [w:] Paradygmaty wspótczesnej dydaktyki, red. L. Hurło, D. Klus-Stańska, M. Łojko, Oficyna Wydawnicza „Impuls”, Kraków 2011, s. 27-39.

${ }^{25}$ A. Krause, Wspótczesne paradygmaty..., s. 153-210. 
szczegółowe modele ${ }^{26}$. Przedstawione propozycje paradygmatów $\mathrm{W}$ pedagogice specjalnej stanowią teoretyczne ramy ujmowania na przestrzeni dziesięcioleci człowieka z niepełnosprawnością, a także dyskutowania o jego miejscu w świecie oraz edukacji. Przykładem jest szczegółowy paradygmat integracyjny, który oznacza zgodę na koegzystencję ludzi pełnosprawnych i tych z niepełnosprawnością. Dotychczasowe doświadczenia pozwalają dokonać rekonstrukcji tego sposobu myślenia. Chodzi o przesunięcie akcentu z koncentracji na strategiach adaptacyjnych osób z niepełnosprawnością na tworzenie warunków integracyjnych zgodnie z założeniami normalizacji „Żyjesz normalnie - jesteś normalny”27. Konieczność eliminowania ograniczeń fizycznych i mentalnych funkcjonowania osób z niepełnosprawnością wynika ze społecznego subparadygmatu niepełnosprawności. Prace Marii Antoniny Ostrowskiej z zespołem ${ }^{28}$ ukazują, jak bardzo tradycja, kultura przypisała człowiekowi z niepełnosprawnością wiele ograniczeń. Dlatego emancypacyjny subparadygmat eksponuje ideę podmiotowości niepełnosprawnych na miarę ich możliwości.

Analizy dyskursów edukacji niesegregacyjnej można dokonać poprzez odwołanie się do różnych teoretycznych ujęć, np. (1) natury człowieka, co pozwala wyłonić trzy ujęcia: behawiorystyczne, humanistyczne i poznawcze 29 , (2) ideologii romantycznej, transmisji kulturowej i progresywizmu wg L. Kohlberga i R. Mayer ${ }^{30}$. Dyskurs, za Michelem Foucaultem, traktowany jest tu jako wzór myślenia o edukacji ${ }^{31}$. W tym kontekście wyróżniono cztery dyskursy dostarczające wzorów myślenia o edukacji niesegregacyjnej: funkcjonalno-behawiorystyczny, humanistyczny, społeczny oraz krytyczno-

${ }^{26}$ Mowa jest np. o modelu medycznym, rehabilitacyjnym, integracyjnym, normalizacyjnym. Zob. I. Chrzanowska, Pedagogika specjalna. Od tradycji do nowoczesności, Oficyna Wydawnicza „Impuls”, Kraków 2015, s. 399-420.

27 A. Krause, Wspótczesne paradygmaty..., s. 196.

28 A. Ostrowska, J. Sikorska, Syndrom niepetnosprawności w Polsce. Bariery integracji, IFiS PAN, Warszawa 1996, s. 153-198.

${ }^{29}$ J. Kozielecki, op. cit., s. 19-92, 183-253, 261-283.

${ }^{30}$ L. Kohlberg, R. Mayer, op. cit., s. 51-94.

${ }^{31}$ M. Foucault za B. Śliwerski, Wspótczesna myśl..., s. 39. 
-emancypacyjny ${ }^{32}$. Źródeł dyskursu funkcjonalno-behawiorystycznego należy się doszukiwać $\mathrm{w}$ funkcjonalizmie, behawioryzmie, pedagogice pozytywistycznej33. Z założeń wyłania się obraz edukacji transmisyjno-podającej, testowych sposobów poznawania wychowanków, indywidualnych programów terapeutycznych dla uczniów oraz działań rehabilitacyjnych mających na celu ich usprawnianie, eliminowanie braków. Korzenie dyskursu humanistycznego tkwią $\mathrm{w}$ psychologii humanistycznej, personalizmie, pedagogice romantyczno-liberalnej ${ }^{34}$. Z założeń wyłania się obraz edukacji, w której akceptuje się potrzeby ucznia oraz kładzie nacisk na jego sprawczość, samoedukację, samorealizację. Akceptacja każdego ucznia pozwala lepiej zaakceptować innych, w tym tych z niepełnosprawnością. Źródeł dyskursu społecznego należy się doszukiwać w psychologii poznawczej, progresywizmie, interakcjonizmie, konstruktywizmie społecznym ${ }^{35}$. Z założeń wyłania się obraz edukacji, w której uwzględnia się dydaktyczny oraz społeczny aspekt, a także rozwija się u wychowanków kompetencje poznawcze i społeczne. Rozwiązywanie przez uczniów problemów naukowych sprzyja uczeniu się treści przewidzianych programem i utrwalaniu demokratycznych tradycji, likwidowaniu uprzedzeń wobec różnych kategorii inności. Dyskurs krytyczno-emancypacyjny ma swoje teoretyczne podstawy $w$ pedagogice krytycznej oraz emancypacyjnej ${ }^{36}$. Z założeń wyłania się obraz edukacji, w której ma miejsce odnowa

32 Podobne typy dyskursów wyróżniała D. Klus-Stańska, Dyskursy pedagogiki wczesnoszkolnej, [w:] Pedagogika wczesnoszkolna - dyskursy, problemy, rozwiazania, red. D. Klus-Stańska, M. Szczepska-Pustkowska, Oficyna Wydawnicza Łośgraf, Warszawa 2012, s. 25-78.

${ }_{33}$ Por. B. Joyce, E. Calhoun, D. Hopkins, Przykłady modeli uczenia się i nauczania, WSiP, Warszawa 1999, s. 43-44; L. Kohlberg, R. Mayer, op. cit., s. 54; J. Kozielecki, op. cit., s. 19-92.

${ }^{34}$ B. Joyce, E. Calhoun, D. Hopkins, op. cit., s. 42-43; L. Kohlberg, R. Mayer, op. cit., s. 61; J. Kozielecki, op. cit., s. 261-286.

${ }^{35}$ B. Joyce, E. Calhoun, D. Hopkins, op. cit., s. 40-42; L. Kohlberg, R. Mayer, op. cit., s. $55-58$.

${ }_{36}$ P. Freire za B. Śliwerski, Wspótczesne teorie i nurty wychowania, Oficyna Wydawnicza „Impuls”, Kraków 1998, s. 261-282; H.A. Giroux, L. Witkowski, Edukacja i sfera publiczna, Oficyna Wydawnicza „Impuls”, Kraków 2010, s. 172-173, 201-220. 
świata poprzez demaskowanie i przeciwdziałanie przemocy symbolicznej. W kształceniu trzeba uwzględniać aktualne problemy społeczne, np. wykluczenia osób ze specjalnymi potrzebami edukacyjnymi, w tym z niepełnosprawnością. Wyposażenie uczniów w kompetencje interpretacyjno-krytyczne umożliwia lepsze rozumienie świata, dostrzeganie istniejących niesprawiedliwości oraz dokonywanie zmian.

Przedstawione dyskursy dostarczyły różnych sposobów myślenia o edukacji niesegregacyjnej. Z prac Bogusława Śliwerskiego, Doroty Klus-Stańskiej wynika, że komunikacja, dialog pomiędzy niektórymi dyskursami jest trudny, a niekiedy wręcz niemożliwy, ponieważ wywodzą się one $\mathrm{z}$ odmiennych stanowisk teoretycznych $^{37}$. Inny pogląd na ten temat prezentuje Dorota Gołębniak, Anna Izabela Brzezińska, Bruce Joyce, Emily Calhoun, Dawid Hopkins $^{38}$. Autorzy uważają, że na poziomie metod można mówić o eklektycznym podejściu do edukacji oraz dopełnianiu się modeli edukacyjnych w działaniu pedagogicznym. Argumentują oni, że w złożonej praktyce wychowawczej podejścia się mieszają. Nie da się wydzielić działań służących jednemu celowi, którego uzasadnienie wynika z przyjęcia jedynie słusznego dyskursu.

\section{Kształcenie integracyjne oraz włączające - poszukiwanie różnic pomiędzy formami edukacji niesegregacyjnej}

Pojęcie edukacji niesegregacyjnej odnosi się do dwóch form kształcenia osób z niepełnosprawnością, tj. w oddziałach integracyjnych oraz klasach powszechnych zgodnie $\mathrm{z}$ rejonem zamieszka-

37 Por. B. Śliwerski, op. cit., s. 25-42; D. Klus-Stańska, op. cit., s. 75-78.

38 A.I. Brzezińska, Psychologia wychowania, [w:] Psychologia. Podręcznik akademicki. Jednostka w społeczeństwie i elementy psychologii stosowanej, t. 3, red. J. Strelau, GWP, Gdańsk 2000, s. 246; B. Joyce, E. Calhoun, D. Hopkins, op. cit., s. 45; D. Gołębniak, Szkota wspomagająca rozwój, [w:] Pedagogika, t. 2, red. Z. Kwieciński, B. Śliwerski, PWN, Warszawa 2003, s. 117-118. 
nia ucznia. Pierwsza forma jest określana jako edukacja integracyjna (kształcenie integracyjne), druga jako edukacja włączająca (inkluzyjna). W Polsce rozwój kształcenia integracyjnego przypada na lata 90. XX wieku. Sposób organizacji oddziałów integracyjnych był wzorowany na rozwiązaniach hamburskich i do dzisiaj nie uległ zasadniczym zmianom ${ }^{39}$. Obecność wychowanków w przedszkolach i szkołach z różnymi ograniczeniami sprawności wymusiła konieczność realizacji dodatkowych zadań, które można odnieść do trzech aspektów funkcjonowania placówek: (1) organizacyjnego, (2) rehabilitacyjnego i (3) społecznego. Organizacyjny aspekt uwzględnia likwidację barier architektonicznych, zmniejszenie liczebności oddziałów do 20 wychowanków, w tym od 3 do 5 uczniów z różnymi niepełnosprawnościami $\mathrm{w}$ klasie, umożliwienie wielopoziomowej pracy podczas zajęć dzięki pomocy nauczyciela wspomagającego, zatrudnienie specjalistów, np. logopedy, rehabilitanta, psychologa, surdopedagoga ${ }^{40}$. W przedszkolach i szkołach zapewnia się uczniom rehabilitację fizyczną, psychologiczną, pedagogiczną, społeczną oraz zawodową. Ważne jest, aby lekcje/zajęcia $\mathrm{w}$ tej formie edukacji miały charakter jednocześnie edukacyjny i rewalidacyjny w stosunku do uczniów z różnymi rodzajami niepełnosprawności. Aspekt społeczny uwzględniania działania edukacyjne mające na celu ingerowanie w dynamikę stosunków społecznych w klasach integracyjnych, budowanie wspólnoty wśród uczestników procesu kształcenia, a także przeciwdziałanie dyskryminacji osób z niepełnosprawnością $\mathrm{w}$ środowisku lokalnym ${ }^{41}$.

Edukacja włączająca/inkluzyjna to model wyrastający z potrzeby zlikwidowania dychotomicznego podziału: pełnosprawny vs. niepełnosprawny uczeń, który miał miejsce w kształceniu integracyjnym. Wprowadzenie do naukowego obiegu pojęcia specjalne po-

${ }^{39} \mathrm{H}$. Wocken, Sind Förderzentren der richtige Weg zur Integration?, "Sonderschule" 1995, 2, s. 84-93.

${ }^{40}$ Rozporządzenie MEN z 21 maja 2001 roku w sprawie ramowych statutów publicznego przedszkola oraz publicznych szkół (Dz.U. z 2001 r. Nr 61, poz. 6240).

${ }^{41} \mathrm{~J}$. Bąbka, Edukacja integracyjna dzieci petnosprawnych i niepetnosprawnych - założenia i rzeczywistość, Wydawnictwo Fundacji Humaniora, Poznań 2001, s. 76-168. 
trzeby edukacyjne, a współcześnie kategorii indywidulane potrzeby rozwojowe i edukacyjne, pozwala uwzględniać szerokie spektrum inności dziecka/ucznia. Z najnowszych przepisów ministerialnych wynika, że niepełnosprawność jest jednym z aspektów indywidulanych potrzeb rozwojowych i edukacyjnych ${ }^{42}$. Mel Ainscow, Thoony Both, Alan Dyson ${ }^{43}$ wyróżniają następujące sposoby rozumienia edukacji włączającej: (1) dbałość o niepełnosprawnych, przejawiających specjalne potrzeby edukacyjne, (2) dbałość o uczniów przedwcześnie opuszczających szkołę ze względów dyscyplinarnych, (3) dbałość o potrzeby uczniów z grup zagrożonych wykluczeniem społecznym, (4) dbałość o uczniów o różnorodnych potrzebach oraz tworzenie „szkoły dla wszystkich”, (5) dbałość o potrzeby wszystkich uczniów tzw. „edukacja dla wszystkich, (6) dbałość o systemowe podejście do edukacji i społeczeństwa". Zdaniem znawców problematyki w inkluzji chodzi o przeniesienie środka ciężkości $\mathrm{z}$ dopasowania się ucznia ze specjalnymi potrzebami (w tym $\mathrm{z}$ niepełnosprawnością) do szkoły na dostosowanie warunków kształcenia do indywidulanych potrzeb psychofizycznych wychowanków w ogólnodostępnym nurcie edukacyjnym ${ }^{44}$.

Grzegorz Szumski, Anna Zamkowska, a także autorzy zachodni, tacy jak Tony Gary Thomas ${ }^{45}$, traktują kształcenie integracyjne i włą-

42 Indywidulane potrzeby rozwojowe i edukacyjnych uczniów wynikają z niepełnosprawności, niedostosowania społecznego, zagrożenia niedostosowaniem społecznym, szczególnych uzdolnień, specyficznych trudności w uczeniu się, zaburzeń komunikacji językowej, choroby przewlekłej, sytuacji kryzysowych lub traumatycznych, niepowodzeń edukacyjnych, zaniedbań środowiskowych, trudności adaptacyjnych związanych z różnicami kulturowymi, wcześniejszego kształcenia za granicą. Zob. Rozporządzenie MEN z dnia 7 maja 2013 r. w sprawie zasad udzielania i organizacji pomocy psychologiczno-pedagogiczne $\mathrm{w}$ publicznych przedszkolach, szkołach i placówkach (Dz.U. z 2013 r., poz. 532).

${ }^{43}$ M. Ainscow, T. Booth, A. Dyson i in., Improving schools: Developing Inclusion, Routledge, London 2006, s. 26.

${ }^{44}$ D. Wiszejko-Wierzbicka, Specjalne potrzeby ucznia czy szkoły? Przewodnik po edukacji wtączającej pomoca w rozwijaniu kształcenia i uczestnictwa w życiu szkoty, "Niepełnosprawność - Zagadnienia, Problemy, Rozwiązania” 2012, 4, s. 72.

${ }^{45}$ Por. G. Szumski, Wokót edukacji wtączającej. Efekty kształcenia uczniów z niepetnosprawnościa intelektualna w stopniu lekkim w klasach specjalnych, integracyjnych i ogólno- 
czające, pomimo dostrzeganych podobieństw, jako nieco odmienne modele edukacji. Zaproponowany przez autorów kierunek myślenia pozwala wyróżnić trzy kryteria ujmowania różnic pomiędzy kształceniem integracyjnym a włączającym: (1) ze względu na lokalizację, (2) grupę tratowaną jako „Inna” oraz (3) model wychowania.

1. Kształcenie integracyjne jest realizowane $w$ wybranych szkołach, zaś edukacja włączająca ma być realizowana w każdej szkole, zgodnie z rejonem zamieszkania wychowanka.

2. W kształceniu integracyjnym zakładano, że grupę tzw. „Innych" stanowią uczniowie $\mathrm{z}$ niepełnosprawnością. Natomiast w edukacji włączającej inność ucznia jest ujmowana w kategorii specjalnych potrzeb edukacyjnych, które oprócz niepełnosprawności dotyczą, np. odmienności narodowościowej, językowej, wybitnej zdolności, trudności edukacyjnych, niedostosowania czy zagrożenia niedostosowaniem społecznym.

3. W kształceniu integracyjnym realizowano model asymilacji, polegający na przystosowaniu się uczniów z niepełnosprawnością, tzw. mniejszości do życia w społeczności pełnosprawnych, stanowiących większość. W podejściu włączającym można mówić o koncepcji różnorodności. Oznacza ona, że świat jest różny i ludzie w nim żyjący są różni ${ }^{46}$.

\section{Edukacja niesegregacyjna jako interwencja w proces socjalizacji - poszukiwanie podobieństw pomiędzy założeniami edukacji integracyjnej i włączającej}

Oprócz różnic pomiędzy kształceniem integracyjnym a włączającym warto doszukiwać się między nimi podobieństw. Kształcenie

dostępnych, Wydawnictwo Akademii Pedagogiki Specjalnej, Warszawa 2009, s. 53-64; T.G. Thomas, Inclusive school for an incusive society, „British Journal of Special Education" 24, s. 103-107; A. Zamkowska, Wsparcie edukacyjne uczniów z upośledzeniem umystowym w stopniu lekkim w różnych formach kształcenia na I etapie edukacji, Wydawnictwo Politechniki Radomskiej, Radom 2009, s. 42.

46 Te kwestie mocno akcentuje M. Foucault za B. Śliwerski, op. cit., s. 315. 
integracyjne i włączające łączy głęboki społeczny sens działań edukacyjnych, a także misja przygotowania młodego pokolenia do akceptacji różnic występujących pomiędzy ludźmi, wzajemnej koegzystencji, dialogu i współpracy. Pomiędzy edukacją integracyjną a włączającą w tym zakresie istnieje wiele podobieństw. W Polsce od lat 90. poprzez kształcenie integracyjne $\mathrm{z}$ różnym skutkiem są podejmowane próby zmiany postaw społeczeństwa wobec osób z różnymi ograniczeniami sprawności, przeciwdziałania stereotypowemu myśleniu o nich jako gorszych, nieprzydatnych i nieproduktywnych. Edukacja włączająca w myśleniu o inności człowieka pozwala wyjść poza różne kategorii niepełnosprawności, uwrażliwić wychowanków na to, że świat jest różny i ludzie w nim żyjący różnią się, a także przeciwdziałać społecznemu wykluczeniu osób z różnych grup ryzyka. Oznacza to, że kształcenie integracyjne oraz włączające można traktować jako społeczną interwencję $\mathrm{w}$ proces socjalizacji. Pedagodzy krytyczni, mając na względzie pożądane zmiany społeczne, podkreślają znaczenie projektowania działań edukacyjnych, co jest zgodnie z logiką interwencji edukacyjnej według K. Hurelmanna ${ }^{47}$. Pojęcie to oznacza działanie polegające na ingerowaniu w rzeczywistość, po to, aby dokonać zmiany określonego stanu rzeczy ${ }^{48}$. Tomasz Szkudlarek uważa, że „wtrącanie się w rzeczywistość" 49 poprzez różnego rodzaju interwencje wymaga od realizatorów świadomości takich kwestii jak:

(1) związek interwencji edukacyjnej z potrzebami społecznymi. Tożsamość i różnica współistnieją w kulturze ${ }^{50}$. Niepełnosprawność jest jednym z wielu aspektów „Inności” człowieka oraz odnosi się do jego indywidulanych potrzeb rozwojowych i edukacyjnych;

${ }^{47}$ K. Hurrelmann, op. cit., s. 155.

${ }^{48}$ P. Wiliński, Interwencja edukacyjna wspomagająca społeczność lokalną: założenia i uzasadniania, [w:] Podmiotowość społeczności lokalnych. Praktyczne programy wspomagania rozwoju, red. R. Cichocki, „Media-G.T.”, Poznań 1996, s. 219-326.

49 T. Szkudlarek, Pedagogika krytyczna, [w:] Pedagogika, t. 1, red. Z. Kwieciński, B. Śliwerski, Wydawnictwo Naukowe PWN, Warszawa 2003, s. 363-377.

${ }^{50}$ H. Giroux, op. cit., s. 413-434. 
(2) związek interwencji edukacyjnej z wartościami, które stanowią podwaliny ładu demokratycznego. Chodzi o promowanie poprzez interwencję edukacyjną wartości szacunku dla inności drugiego człowieka, aksjologicznej heterodoksyjności, solidarności społecznej, praw obywatelskich;

(3) związek interwencji edukacyjnej z kompetencjami osobistymi i społecznymi wychowanków, a w przyszłości obywateli społeczeństwa otwartego. Ważne jest rozwijanie poprzez działania edukacyjne kompetencji działaniowych takich jak wiedza, refleksyjność, umiejętność uczenia się i podejmowania decyzji oraz kompetencji społecznych: empatii, komunikowania się, nastawienia na dialog, otwartości na innych, umiejętności współpracy z ludźmi pomimo występujących między nimi różnic.

Z wcześniejszych rozważań wynika, że edukacja niesegregacyjna, w tym kształcenie integracyjne i włączające, ze względu na społeczny sens mogą być traktowane jako swoista interwencja w proces socjalizacji, której źródeł należy się doszukiwać w dyskursie społecznym. Jeromy Bruner ${ }^{51}$ uważa, że wyzwaniem dla współczesnej edukacji jest podtrzymywanie demokratyczności kultury. Problemy płci, rasy, religii, pochodzenia etnicznego oraz niepełnosprawności można rozwiązywać poprzez debatę, dialog i współpracę. Każdą interwencję edukacyjną należy ujmować ze względu na jej podwójny charakter. Oznacza to, że interwencja edukacyjna ingeruje w rzeczywistość indywidualną wychowanka, w jego kompetencje, wartości, postawy. Ponadto interwencja edukacyjna narusza rzeczywistość społeczną, w tym kulturowy świat znaczeń. Podwójny charakter interwencji edukacyjnej polega na tym, że z jednej strony przyczynia się do zmiany osoby, z drugiej strony przyczynia się do zmian $\mathrm{w}$ kulturze. To one wymuszają na jednostce zmianę dotychczasowych sposobów działania oraz jej prywatnego świata znaczeńn ${ }^{52}$.

51 J.S. Bruner, Kultura edukacji, TW i WPN Universitas, Kraków 2006, s. 138-140.

52 A. Brzezińska, Model edukacji dla obywatelskiej wspótpracy: interwencja edukacyjna wspomagająca społeczność lokalna, [w:] Podmiotowość społeczności lokalnych. Praktyczne programy wspomagania rozwoju, red. R. Cichocki, „Media-G.T.”, Poznań 1996, 
Podwójny charakter działań edukacyjnych dotyczy zarówno (1) kompetencji twardych u wychowanków, tj. wiedzy u umiejętności przewidzianych programem, jak i (2) kompetencji miękkich, związanych z otwartością na drugiego człowieka, afirmacją różnic pomiędzy ludźmi jako czegoś naturalnego w kurczącym się na skutek globalizacji świecie. $Z$ dotychczasowej praktyki integracyjnej wynika, że uwzględnienie podwójnego charakteru interwencji jest niezmiernie trudne, bowiem koncentracja na jednym aspekcie edukacji powoduje zaniedbywanie drugiego ${ }^{53}$.

\section{Dylematy edukacji niesegregacyjnej - próba łagodzenia stanowisk}

$\mathrm{Z}$ wielu prac wynika, że kształcenie uczniów z niepełnosprawnością powinno postępować, tam gdzie tylko jest to możliwe, w kierunku edukacji włączającej ${ }^{54}$. Edukacja włączająca, jako postulowany model szkoły dla różnorodności wychowanków oraz związana z nim pedagogika różnic, to ciekawe koncepcje, którym na poziomie teoretycznym trudno jest odmówić słuszności. W Rozporządzeniu Ministerstwa Edukacji Narodowej z dnia 24 lipca 2015 r. w sprawie warunków organizowania kształcenia, wychowania i opieki dla dzieci i młodzieży niepełnosprawnych, niedostosowanych społecznie i zagrożonych niedostosowaniem społecznym usankcjonowano specjalną, integracyjną oraz włączającą formę edukacji uczniów z niepełnosprawnością. Uregulowano też kwestię dotyczącą możliwości zatrudniania nauczycieli posiadających kwalifikacje w zakresie pedagogiki specjalnej lub specjalistów, asystenta w przypadku klas I-III albo pomocy nauczyciela w celu współorganizacji kształcenia uczniów z niepełnosprawnością w szkołach

s. $195-218$.

${ }^{53}$ J. Bąbka, op. cit., s. 233-236.

${ }^{54}$ D. Wiszejko-Wierzbicka, Specjalne potrzeby ucznia, s. 74, 84; A. Firkowska-Mankiewicz, Edukacja włączająca - wyzwaniem dla polskiej szkoły, „Szkoła Specjalna” 2004, 1, s. 19-25. 
ogólnodostępnych. W kształceniu integracyjnym i inkluzyjnym wymaga się od nauczycieli opracowania dla ucznia posiadającego orzeczenie o potrzebie kształcenia specjalnego indywidulanego programu edukacyjno-terapeutycznego. Program ma uwzględniać m.in.: zakres wymagań dostosowanych do możliwości ucznia, sposoby oceniania i klasyfikowania, zintegrowane działania nauczycieli i specjalistów o charakterze rewalidacyjnym, formy pomocy psychologiczno-pedagogicznej, zakres współpracy nauczycieli, specjalistów i rodziców ${ }^{55}$. Wynika $\mathrm{z}$ tego, że w aktualnej polityce oświatowej niesegregacyjne formy edukacji uczniów z niepełnosprawnością traktowane są jako dopełniające się. Wątpliwości budzi przygotowanie nauczycieli szkół ogólnodostępnych do edukacyjnego spotkania z uczniem z niepełnosprawnością. $\mathrm{Z}$ analizy doświadczeń wybranych szkół powszechnych w województwie lubuskim wynika, że realizacja zadań rehabilitacyjnych (rewalidacyjnych) w stosunku do uczniów z niepełnosprawnością odbywa się przy wykorzystaniu posiadanych zasobów kadrowych placówek, w tym potencjału zatrudnionych wcześniej nauczycieli56. We Włoszech, kolebce kształcenia włączającego, nauczyciel wspierający pracuje w klasie, w której edukację realizuje nawet jeden uczeń $\mathrm{z}$ niepełnosprawnością ${ }^{57}$. Dlatego w polskich realiach ze względu na liczebność klas oraz zatrudnianie nauczycieli wspomagających i specjalistów zdecydowanie lepiej wypada kształcenie integracyjne w porównaniu z włączającym. Kształcenie integracyjne jest krytykowane za nadmierny nacisk na usprawnianie ucznia, strategie adaptacyjne niepełnosprawnych do otoczenia, medykalizację działań, co odpowiada za-

55 Rozporządzenie MEN z dnia 24 lipca 2015 r. w sprawie warunków organizowania kształcenia, wychowania i opieki dla dzieci i młodzieży niepełnosprawnych, niedostosowanych społecznie i zagrożonych niedostosowaniem społecznym (Dz.U. z 2015 r., poz. 1113).

56 J. Bąbka, M. Podgruszewska, Realizacja polityki oświatowej uczniów ze specjalnymi potrzebami edukacyjnymi w perspektywie lokalnej - na przykładzie matego miasta (niepublikowany maszynopis).

57 Ministero dell'Istruzione, dell'Università e della Ricerca Dipartimento per l'istruzione Direzione Generale per il personale scolastico Decreto n. 7 Il Direttore Generale, http:/ / www.scolastica.it [30.06.2015]. 
łożeniom paradygmatu biologicznego i dyskursu funkcjonalnobehawiorystycznego ${ }^{58}$. Te i inne niedoskonałości ma przezwyciężyć edukacja włączająca. Istnieje potrzeba dyskusji na temat tego, co mają na myśli zwolennicy inkluzji, krytykując charakterystyczną dla kształcenia integracyjnego, np. rozbudowę specjalnej infrastruktury na terenie szkół, pisanie programów indywidulanych dla poszczególnych uczniów i ich rehabilitację ${ }^{59}$. Rodzi się pytanie, czy można lekceważyć swoiste cechy uczniów wynikające z niepełnosprawności oraz nie oddziaływać na nie poprzez zabiegi usprawniające i korygujące? W literaturze dotyczącej edukacji inkluzyjnej brakuje wyjaśnienia takich kwestii jak np.: (1) na czym polega wspieranie różnorodności wszystkich wychowanków w klasie, (2) co oznacza szkoła dostosowana do heterogenicznych potrzeb uczniów, która traktuje różnice pomiędzy nimi jako normalność, (3) jak tworzyć inkluzyjną kulturę?

Należy zgodzić się z Zenonem Gajdzicą, że rehabilitacja wychowanka $\mathrm{z}$ niepełnosprawnością nie może być celem samym w sobie. Bardziej chodzi o to, aby rehabilitacja pomagała mu lepiej odgrywać rolę ucznia i kolegi60. Pożądany jest model edukacji, w którym nie rezygnuje się $\mathrm{z}$ działań rehabilitacyjnych wobec uczniów z niepełnosprawnością, ale nie zaniedbuje się afirmacji różnorodności, dialogu i współpracy, co wynika z założeń dyskursu społecznego oraz emancypacyjnego. Takie podejście nawiązuje do koncepcji poruszania się pomiędzy paradygmatami dydaktycznymi, o czym pisała Joanna Rutkowiak61. Biorąc pod uwagę aktualne funkcjonowanie polskich szkól, trudno jest się zgodzić z teza-

58 Por. A. Krause, op. cit., s. 214; Z. Gajdzica, Kategorie sukcesów w opiniach nauczycieli klas integracyjnych jak przyczynek do poszukiwania koncepcji edukacji integracyjnej, Oficyna Wydawnicza „Impuls”, Kraków, s. 196-205.

59 A. Firkowska-Mankiewicz, Edukacja - narzędziem przeciw wykluczeniu społecznemu osób z niepetnosprawnościa, [w:] Przeciw wykluczeniu społecznemu osób niepetnosprawnych, red. L. Frąckiewicz, Warszawa 2008, s. 226; G.L. Porter, A. Hinz za Szumski, Integracyjne ksztatcenie niepetnosprawnych, Wydawnictwo Naukowe PWN, Warszawa 2006, s. 24.

${ }^{60}$ Z. Gajdzica, op. cit., s. 237.

61 J. Rutkowiak, op. cit., s. 27. 
mi niektórych autorów, że inkluzja rozwiąże wszystkie problemy i niedoskonałości integracyjnego kształcenia ${ }^{62}$. Hans Wocken ${ }^{63}$, znawca problemu, który śledzi proces realizacji idei edukacji włączającej w kraju o dłuższej tradycji proinkluzyjnej, uważa, że myśląc $\mathrm{w}$ taki sposób o inkluzji poruszamy się w „krainie cudów”. Jaką mamy gwarancję, że uczniowie z ograniczeniami sprawności nie będą stygmatyzowani w szkołach powszechnych? Czy nauczyciele szkół masowych będą potrafili tak zorganizować lekcję w klasie heterogenicznej, aby sprzyjała rozwojowi wszystkich uczniów, w tym ze specjalnymi potrzebami edukacyjnymi, a w szczególności z niepełnosprawnością? Wszak kształcenie włączające, zgodnie z ideą, powinno uwzględniać zróżnicowane potrzeby wszystkich uczniów. Badacze włoscy dowodzą, że u nauczycieli zaangażowanych $\mathrm{w}$ realizację inkluzji znacznie obniża się gotowość do innowacji w porównaniu z latami 80., kiedy wcielano w życie ideały inkluzyjne ${ }^{64}$.

Wiele wątpliwości budzą niezadowalające efekty dydaktyczne i społeczne uczniów $\mathrm{z}$ niepełnosprawnością $\mathrm{w}$ różnych formach kształcenia. Ta problematyka wymaga oddzielnego opracowania. W niniejszej pracy skoncentrowano się jedynie na efektach edukacyjnych $\mathrm{w}$ odniesieniu do uczniów z niepełnosprawnością intelektualną, którym ze względu na mniejsze możliwości poznawcze najtrudniej jest odnaleźć się w szkole. $Z$ badań wynika, że najlepsze rezultaty dydaktyczne $\mathrm{w}$ zakresie języka polskiego i matematyki uzyskują uczniowie z klas integracyjnych, potem klas masowych (inkluzja), a następnie szkół specjalnych ${ }^{65}$. W szkołach integracyjnych i masowych nie uzyskuje się natomiast pożądanych efektów

62 A. Firkowska-Mankiewicz, Edukacja włączająca..., s. 23; G. Szumski, Wokót edukacji wtaczajacej..., s. 37-38.

${ }^{63} \mathrm{H}$. Wocken za O. Speck, op. cit., s. 77.

${ }^{64}$ D. Ianes, Die besondere Normalität. Inklusion von SchülerInnen mit Behinderung, Ernst Reinhardt, Monachium 2009, s. 43.

${ }_{65}$ Por. I. Chrzanowska, Funkcjonowanie dzieci upośledzonych umystowo w stopniu lekkim w szkole podstawowej, Wydawnictwo Uniwersytetu Łódzkiego, Łódź 2003, s. 80-87; G. Szumski, op. cit., s. 53-64; A. Zamkowska, op. cit., s. 252-267. 
społecznych. Bardziej satysfakcjonujące relacje z rówieśnikami deklarują uczniowie szkół specjalnych, a następnie badani ze szkół integracyjnych. Najniższy wskaźnik zadowolenia z relacji społecznych deklarowali uczniowie z klas ogólnodostępnych ${ }^{66}$. Iwona Chrzanowska dostarczyła dowodów na temat niezadowalającej realizacji standardów związanych $\mathrm{z}$ organizacją i prowadzaniem zajęć wspomagających rozwój uczniów z niepełnosprawnością, dostosowaniem programów nauczania do ich potrzeb i możliwości oraz dostępnością pomieszczeń szkolnych dla uczniów (bariery architektoniczne, brak odpowiedniego sprzętu) w szkołach masowych na terenie Łodzi. Uzyskane dane można ekstrapolować na inne aglomeracje miejskie w Polsce ${ }^{67}$. Wyniki badań zmuszają do refleksji na temat niewydolności systemu włączającego w stosunku do uczniów z różnymi rodzajami niepełnosprawności. Rozważania nie mają na celu deprecjonowania idei edukacji włączającej ani ukazywania wyższości założeń integracyjnego kształcenia. Zasadniejsze jest podkreślenie znaczenia przygotowania polskiej szkoły do realizacji wyzwań związanych z dostosowaniem warunków kształcenia do indywidulanych potrzeb rozwojowych i edukacyjnych uczniów. Wynika z tego, że edukacja włączająca wymusza nowy model kształcenia nauczycieli nie tylko nauczania początkowego, którzy na ten temat sporo już widzą, lecz także np. polonistów czy matematyków oraz przygotowania ich do refleksyjnego myślenia o szkole i uczniach w kategorii różnorodności. Pedagodzy nie od razu mogą wprowadzać zmiany wynikające $z$ reform oświatowych oraz po otrzymaniu zalet edukacji włączającej. Wymagane są przemiany w ich prywatnych teoriach edukacyjnych, bowiem to one generują zmiany w stylu działania. Każdy nauczyciel ma swoją własną prywatną teorię edukacji i w pracy z wychowankiem kieruje

66 Por. S. Sadowska, Jakość życia uczniów z niepetnosprawnościa intelektualna w stopniu lekkim, Oficyna Wydawnicza „Impuls”, Kraków 2006, s. 237-250; A. Zamkowska, op. cit., s. 249 i inne.

${ }^{67}$ Szerzej: I. Chrzanowska, Problem edukacji dzieci i młodzieży z niepetnosprawnością. Regionalna specyfika czy ogólnopolska tendencja, Oficyna Wydawnicza "Impuls”, Kraków 2010, s. 27-74. 
się jakąś ukrytą koncepcją zmiany, której źródeł można się doszukiwać w omówionych wcześniej dyskursach.

Integracyjnemu kształceniu, społecznej integracji przypisywane są konotacje ideologiczne ${ }^{68}$. Zdaniem Rolanda Meighna ${ }^{69} \mathrm{z}$ punktu widzenia ukrytego programu u podstaw każdej edukacji znajduje się jakaś ideologia. Ważne jest, aby nie robić z niej jedynej i słusznej. Współczesne przemiany $\mathrm{w}$ podejściu do osób $\mathrm{z}$ niepełnosprawnością polegają na tym, że proces normalizacji, którego wyrazem jest edukacja włączająca, stanowi drogę do społecznej integracji. $Z$ kolei społeczną integrację warto rozważyć jako rodzaj oferty dla niepełnosprawnych $\mathrm{w}$ środowisku lokalnym, z której mogą, ale nie muszą skorzystać ${ }^{70}$. Tendencje indywidualistyczne oraz zanik więzi społecznych we współczesnym świecie powodują, że każdemu człowiekowi, bez względu na to, czy jest pełnosprawny, czy niepełnosprawny, trudno jest doświadczać poczucia integracji z szerszymi grupami społecznymi. Warto podkreślić, że koncepcja społecznej integracji w odniesieniu do klasy szkolnej, jako grupy uczniów, bez względu na formę kształcenia, nie jest zdezaktualizowanym sloganem oraz ciągle znajduje naukowe uzasadnienie. Klasa szkolna, jako grupa społeczna, jest miejscem licznych interakcji pomiędzy wychowankami, ścierania się poglądów, konfliktów, dynamicznie zmieniających się stosunków społecznych. Pożądanym efektem działań wychowawczych w modelu integracyjnym i włączającym jest zintegrowana grupa wychowanków, brak osób izolowanych oraz odrzucanych, a także gotowość uczniów do współpracy ze sobą ${ }^{71}$.

68 A. Krause, op. cit., s. 158-159.

${ }^{69}$ R. Meighan, Socjologia edukacji, przeł. E. Kiszkurno-Koziej, Z. Knusten, P. Kwieciński, Uniwersytet Mikołaja Kopernika, Torun 1993, s. 191-214.

70 A. Krause, A. Żyta, S. Nosażewska, Normalizacja środowiska społecznego osób $z$ niepetnosprawnościq intelektualna, Wydawnictwo Edukacyjne Akapit, Torun 2010, s. $40-47$.

${ }^{71}$ Zob. A. Maciarz, Integracja spoteczna dzieci niepetnosprawnych, WSiP, Warszawa 1987; H. Sowińska, Dynamika przemian klasowych, Wydawnictwo Naukowe UAM, Poznań 1988 i inne. 


\section{Zakończenie}

Aktualnie kształcenie integracyjne oraz włączające stanowią dopełniające się, a nie wykluczające formy edukacji osób z niepełnosprawnością. Zastępowanie pojęcia społecznej integracji normalizacją oraz wypieranie kształcenia integracyjnego postulowaną formą edukacji inkluzyjnej wcale nie musi wiązać się z uzyskiwaniem pożądanych rezultatów dydaktycznych i społecznych. W opracowaniu starano się podkreślić, że skuteczność edukacji niesegregacyjnej nie tkwi w nomenklaturze, zastępowaniu jednych pojęć drugimi, ani odgórnym wprowadzaniu przepisów ministerialnych. Ważniejsze są głębsze przemiany u nauczycieli w sposobach myślenia o uczniu i jego edukacji, kompetencyjnym przygotowaniu pedagogów do realizacji nowych idei. $W$ kontekście niniejszych rozważań słuszny wydaje się pogląd Otto Specka, że „Nowe musi umieć nawiązać do tego, co już istnieje"72. W procesie otwierania się na ideę edukacji włączającej, której słuszności się nie kwestionuje, warto jest wykorzystać naukowy dorobek oraz dobre praktyki związane z integracyjnym kształceniem.

\section{Bibliografia}

Ainscow M., Booth T., Dyson A. i in., Improving schools: Developing Inclusion, Routledge, London 2006.

Bąbka J., Edukacja integracyjna dzieci petnosprawnych i niepetnosprawnych - zatożenia i rzeczywistość, Wydawnictwo Fundacji Humaniora, Poznań 2001.

Bąbka J., Podgruszewska M., Realizacja polityki oświatowej uczniów ze specjalnymi potrzebami edukacyjnymi w perspektywie lokalnej - na przyktadzie małego miasta (niepublikowany maszynopis).

Ball S.J., Foucault i edukacja. Dyscypliny $i$ wiedza, Oficyna Wydawnicza „Impuls”, Kraków 1992.

Booth T., Ainscow M., Index for Inclusion. Developing learning and participation in schools, revised edition, CSIE, Bristol 2002.

Bronfenbrenner U., The Ecology of Human Development, Harvard University Press, Cambridge 1979.

72 O. Speck, op. cit., s. 23. 
Bruner J., Kultura edukacji, Universitas, Kraków 2006.

Brzezińska A., Model edukacji dla obywatelskiej wspótpracy: interwencja edukacyjna wspomagająca społeczność lokalna, [w:] Podmiotowość społeczności lokalnych. Praktyczne programy wspomagania rozwoju, red. R. Cichocki, Media-G.T., Poznań 1996.

Brzezińska A.I., Pomoc dzieciom z grup ryzyka, „Remedium” 12.

Brzezińska A.I., Psychologia wychowania, [w:] Psychologia. Podręcznik akademicki. Jednostka w spoleczeństwie i elementy psychologii stosowanej, t. 3, red. J. Strelau, GWP, Gdańsk 2000.

Chrzanowska I., Funkcjonowanie dzieci upośledzonych umysłowo w stopniu lekkim w szkole podstawowej, Wydawnictwo Uniwersytetu Łódzkiego, Łódź 2003.

Chrzanowska I., Problem edukacji dzieci i młodzieży z niepetnosprawnością. Regionalna specyfika czy ogólnopolska tendencja, Oficyna Wydawnicza „Impuls”, Kraków 2010.

Chrzanowska I., Pedagogika specjalna. Od tradycji do wspótczesności, Oficyna Wydawnicza „Impuls”, Kraków 2015.

Deklaracja madrycka uchwalona podczas Europejskiego Kongresu na Rzecz Osób Niepełnosprawnych, Madryt 20-24 marca 2002.

Deklaracja z Salamanki oraz Wytyczne dla działania w zakresie specjalnych potrzeb edukacyjnych przyjęte przez Światową Konferencję dotyczącą Specjalnych Potrzeb Edukacyjnych: Dostęp i Jakość, UNESCO, Salamanka, Hiszpania, 7-10 czerwca 1994.

Dykcik W., Wprowadzenie w przedmiot pedagogiki specjalnej jako nauki, [w:] Pedagogika specjalna, red. W. Dykcik, Wydawnictwo Naukowe UAM, Poznań 2001.

Firkowska-Mankiewicz A., Edukacja włączająca- wyzwaniem dla polskiej szkoły, „Szkoła Specjalna" 2004, 1.

Firkowska-Mankiewicz A., Edukacja - narzędziem przeciw wykluczeniu społecznemu osób z niepetnosprawnościa, [w:] Przeciw wykluczeniu społecznemu osób niepetnosprawnych, red. L. Frąckiewicz, Warszawa 2008.

Gajdzica Z., Kategorie sukcesów w opiniach nauczycieli klas integracyjnych jak przyczynek do poszukiwania koncepcji edukacji integracyjnej, Oficyna Wydawnicza "Impuls”, Kraków 2013.

Giroux H.A., Wobec wyzwań tożsamości i różnicy (Poza dyskurs edukacji wielokulturowej), [w:] Edukacja wobec zmiany społecznej, red. J. Brzeziński, L. Witkowski, Wydawnictwo Edytor, Poznań - Torun 1994.

Giroux A.H., Witkowski L., Edukacja i sfera publiczna, Oficyna Wydawnicza „Impuls", Kraków 2010.

Gnitecki J., Zarys pedagogiki ogólnej, Wojewódzki Ośrodek Metodyczny, Gorzów Wielkopolski 1999.

Gołębniak D., Szkoła wspomagająca rozwój, [w:] Pedagogika, t. 2, red. Z. Kwieciński, B. Śliwerski, PWN, Warszawa 2003.

Hejnicka-Bezwińska T., Paradygmat humanistyczny w pedagogice a pedagogika humanistyczna, [w:] Edukacja, moralność, sfera publiczna. Materiały z VI Ogólnopolskiego 
Zjazdu Pedagogicznego PTP, red. J. Rutkowiak, D. Kubinowski, M. Nowak, Oficyna Wydawnicza „Verba”, Lublin 2007.

Hurrelmann K., Struktura społeczna a rozwój osobowości. Wprowadzenie do teorii socjalizacji, Wydawnictwo Naukowe UAM, Poznań 1994.

Ianes D., Die besondere Normalität. Inklusion von SchülerInnen mit Behinderung, Ernst Reinhardt, Monachium 2009.

Joyce B., Calhun E., Hopkins D., Przykłady modeli uczenia się i nauczania, Wydawnictwa Szkolne i Pedagogiczne, Warszawa 1999.

Klus-Stańska D., Dyskursy pedagogiki wczesnoszkolnej, [w:] Pedagogika wczesnoszkolna dyskursy, problemy, rozwiazania, red. D. Klus-Stańska, M. Szczepska-Pustkowska, Oficyna Wydawnicza Łośgraf, Warszawa 2012.

Kohlerg L., Mayer R., Rozwój jako cel wychowania, [w:] Spory o edukację. Dylematy $i$ kontrowersje we wspótczesnych pedagogiach, red. Z. Kwieciński, L. Witkowski, Instytut Badań Edukacyjnych, Warszawa 1993.

Konwencja o Prawach Osób Niepełnosprawnych ratyfikowana przez Polskę 6 września 2012 r.

Kowalik S., Pomiędzy dyskryminacją a integracją osób niepetnosprawnych, [w:] Wspomaganie rozwoju. Psychostymulacja i psychokorekcja, t. 3, red. B. Kaja, Wydawnictwo Uczelniane Akademii Bydgoskiej, Bydgoszcz 2001.

Kozielecki J., Psychologiczne koncepcje człowieka, Wydawnictwo Akademickie „Żak” Warszawa 2000.

Krause A., Człowiek niepetnosprawny wobec przeobrażeń społecznych, Oficyna Wydawnicza „Impuls”, Kraków 1992.

Krause A., Wspótczesne paradygmaty pedagogiki specjalnej, Oficyna Wydawnicza „Impuls", Kraków 2010.

Krause A., Żyta A., Nosażewska S., Normalizacja środowiska społecznego osób z niepetnosprawnościa intelektualna, Wydawnictwo Edukacyjne Akapit, Toruń 2010.

Maciarz A., Integracja społeczna dzieci niepetnosprawnych, WSiP, Warszawa 1987.

Meighan R., Socjologia edukacji, przeł. E. Kiszkurno-Koziej, Z. Knusten, P. Kwieciński, Uniwersytet Mikołaja Kopernika, Torun 1993.

Ostrowska A., Sikorska J., Syndrom niepetnosprawności w Polsce. Bariery integracji, IFiS PAN, Warszawa 1996.

Rorty R., Filozofia a nadzieja na lepsze społeczeństwo, przeł. J. Grygieńć, S. Tokariew, Wydawnictwo Naukowe Uniwersytetu Mikołaja Kopernika, Torun 2013.

Rubacha K., Budowanie teorii pedagogicznych, [w:] Pedagogika, t. 1, red. Z. Kwieciński, B. Śliwerski, PWN, Warszawa 2003.

Rutkowiak J., Wielość paradygmatów dydaktyki a wspólny mianownik realności życia. Ku pytaniom o przekłady międzyparadygmatyczne, [w:] Paradygmaty wspótczesnej dydaktyki, red. L. Hurło, D. Kluś-Stańska, M. Łojko, Oficyna Wydawnicza „Impuls”, Kraków 2009.

Sadowska S., Jakość życia uczniów z niepetnosprawnościa intelektualna w stopniu lekkim, Oficyna Wydawnicza „Impuls”, Kraków 2006. 
Śliwerski B., Wspótczesna myśl pedagogiczna. Znaczenia, klasyfikacje, badania, Oficyna Wydawnicza „Impuls”, Kraków 2011.

Śliwerski B., Współczesne teorie i nurty wychowania, Oficyna Wydawnicza "Impuls”, Kraków 1998.

Sowińska H., Dynamika przemian klasowych, Wydawnictwo Naukowe UAM, Poznań 1988. Speck O., Inkluzja edukacyjna a pedagogika lecznicza, Harmonia, Gdańsk 2013.

Szkudlarek T. Pedagogika krytyczna, [w:] Pedagogika, t. 1, red. Z. Kwieciński, B. Śliwerski, Wydawnictwo Naukowe PWN, Warszawa 2003.

Szumski G., Wokót edukacji włączającej. Efekty kształcenia uczniów z niepetnosprawnościa intelektualna w stopniu lekkim w klasach specjalnych, integracyjnych i ogólnodostępnych, Wydawnictwo Akademii Pedagogiki Specjalnej, Warszawa 2010.

Szumski G., Integracyjne ksztatcenie niepetnosprawnych, PWN, Warszawa 2004.

Thomas G., Inclusive school for an inclusive society, "British Journal of Special Education” 1997, 24.

Wiliński P., Interwencja edukacyjna wspomagająca społeczność lokalną: założenia i uzasadniania, [w:] Podmiotowość społeczności lokalnych. Praktyczne programy wspomagania rozwoju, red. R. Cichocki, Media-G.T., Poznań 1996.

Wiszejko-Wierzbick D., Specjalne potrzeby ucznia czy szkoty? Przewodnik po edukacji włączającej pomoca w rozwijaniu kształcenia i uczestnictwa w życiu szkoty, "Niepełnosprawność - Zagadnienia, Problemy, Rozwiązania” 2012, 4.

Wocken H., Sind Förderzentren der richtige Weg zur Integration?, „Sonderschule” 1995, 2.

Zamkowska A., Wsparcie edukacyjne uczniów z upośledzeniem umysłowym w stopniu lekkim w różnych formach kształcenia na I etapie edukacji, Wydawnictwo Politechniki Radomskiej, Rzeszów 2009.

\section{Rozporządzenia Ministerstwa Edukacji Narodowej}

Rozporządzenie MEN z 21 maja 2001 r. w sprawie ramowych statutów publicznego przedszkola oraz publicznych szkół (Dz.U. z 2001 r. Nr 61, poz. 624).

Rozporządzenie MEN z dnia 7 maja 2013 r. w sprawie zasad udzielania i organizacji pomocy psychologiczno-pedagogiczne w publicznych przedszkolach, szkołach i placówkach (Dz.U. z 2013 r., poz. 532).

Rozporządzenie MEN z dnia 24 lipca 2015 r. w sprawie warunków organizowania kształcenia, wychowania i opieki dla dzieci i młodzieży niepełnosprawnych, niedostosowanych społecznie i zagrożonych niedostosowaniem (Dz.U. z 2015 r., poz. 1113).

\section{Netografia}

Ministero dell'Istruzione, dell'Università e della Ricerca Dipartimento per l'istruzione Direzione Generale per il personale scolastico Decreto n. 7 Il Direttore Generale http:/ / www.integrazionescolastica.it [30.06.2015]. 